\title{
EVALUATING AND IMPROVING BLASTING RESULTS AT TOURAH LIMESTONE QUARRY- HELWAN, EGYPT.
}

\author{
SAEED S.ABD EL HAFIZ1, MOSTAFA TANTAWY', ELSEMAN \\ ABDEL-RASOUL ${ }^{1}$, M. ABDEL TAWAB ELGENDI ${ }^{2}$, and M.M. EI- \\ BEBLAWY ${ }^{1}$ \\ ${ }^{I}$ Department of Mining and Metallurgical Engineering, Assiut University, \\ Assiut, (State ZIP/Zone), Egypt \\ ${ }^{2}$ Department of Mining Engineering, Suez Canal University, Suez, (State \\ ZIP/Zone), Egypt
}

(Received March 18, 2010 Accepted May 20, 2010)

\begin{abstract}
Evaluation of blast performance is considered of high interest for mine operators to improve blasting results. Within the scope of this study, the aim is to determine the optimum blasting conditions in Tourah-quarry, Helwan, Egypt. Guidelines have been suggested for a step-by-step trial blasts to evaluate blasting results in Tourah quarry. Thirty full scale production blasting events in Tourah quarry have been conducted and the results have been recorded. Two design parameters have been investigated. These parameters are initiation point and primer location inside the blast hole. The objective has been achieving optimum blast results: adequately displaced and swelled muck pile; desired fragmentation degree; less uneven rock face and minimum environmental problems such as ground vibrations, and flying rock.
\end{abstract}

\section{1- INTRODUCTION}

One of the most frequently encountered requirements of mining operations in which rock is broken using bench blasting techniques, is the need to produce a well fragmented muck pile which will "dig" easily and to cause less environmental impact. In bench blasting, the realization of an economic and safe blasting is only possible with a reliable and good blasting design on condition that considering all subsequent activities such as mucking, loading, transportation, and crushing.

Explosive energy is consumed in rock fracturing and fragmentation, displacement of fragmented rock, ground vibrations, fly rock, air blast and other losses in form of light and heat. High efficiency blasting directs as much energy as possible into fragmentation. An energy efficient blast is one that results in optimal rock fragmentation; with low ground vibration and less fly rock ${ }^{[1]}$. As the importance of blasting is well known in the production cycle, many studies have been concentrated on the parameters affecting the blast efficiency. Different working conditions complicate the blast design. In addition, blasting is a complex operation affected by many factors which have been indicated by many authors ${ }^{[2-10]}$.

This paper presents an attempt to improve overall blasting efficiency in Tourah quarry. The field procedures conducted at Tourah quarry was investigated to provide data to quantify the blasting performance within the following parameters:

- Amount of oversize exceeding crusher opening $(\geq 1 \mathrm{~m})$. 
- Muck pile displacement and height.

- Maximum distance of fly rock.

- Ground vibration levels.

Thorough recording of the full scale production trial blasting practices and blasting results have been carried out. Results have been analyzed in the search for the effect of the initiation point of the blast and primer location inside the blast hole.

\section{LOCATION AND SITE DESCRIPTION}

The limestone quarry of Toura Cement Company (TCC) is opened up at the south west foot slopes of Tourah Mountain, which forms the eastern high escarpments overlooking the Nile, and situated $23 \mathrm{~km}$ (14.3 miles) south of Cairo, on MaadiHelwan road. Geologically, this area belongs to Mokattam Formation (Middle Eocene). Figure 1 provides a topographic map for Toura quarry.

The quarry deposit is mainly composed of thick bedded limestone, mostly earthy white to faint yellow in the upper $60.0 \mathrm{~m}$ (196.8 feet) turning to greyish yellow and grey downwards. In the upper $60.0 \mathrm{~m}$ (196.8 feet) two segments of thickness $4.0 \mathrm{~m}$ (13.1 feet) each, are composed of nodular limestone. The hardness of the limestone deposit is considerably varying from moderately hard to very hard.

Fissures are more frequent near the top and less frequent downwards. Most of these fissures are filled with iron oxides and siliceous sediments. The noticeable structures in the area are a group of step faults running east-west, and perpendicular to the investigated site ${ }^{[11]}$.

\section{3- FIELD WORK}

Thirty full scale production blasts using NONEL system have been performed at the limestone quarry of Tourah Cement Company. In these blasts we have used multi-deck charging system in the blast hole to decrease the level of ground vibrations resulting from the blasts. That is because there are some historical caves near to the quarry. In Tourah quarry there are two benches. The lower one is of height $\approx 55 \mathrm{~m}$, and the upper one is of height $\approx 30 \mathrm{~m}$. In our study we performed blasts in both benches. Figure 2 presents an example of deck charging of the blast holes.

Our study has two objectives:

1- Investigation of the effect of the location of initiation point:

a- At the middle of the blast.

b- At one side of the blast.

2- Investigation of the effect of the location of the primer:

a- At the bench floor (zero distance from the bench floor).

b- At $5 \mathrm{~m}$ above the bench floor.

c- At $10 \mathrm{~m}$ above the bench floor.

\section{4- RESULTS AND DISCUSSION}

Results of the blasts such as fly rock distance, ground vibrations, boulders \% (as fragmentation index), muck pile shape, formation of toe and back break ... etc. has been documented. Table1 presents summary of average magnitudes of results. 


\section{Effect of primer location and point of initiation:}

Fragment of size greater than one meter are considered oversize boulders according to maximum dimension of the crusher opening (greater than $1 \mathrm{~m}$ ). Figure 3 shows a bar graph for the average percentage of the oversize boulders (as a fragmentation index). The figure shows that primer location at five meters from the bench floor produces minimum percentage of boulders for both upper and lower benches. That is true for the two cases of middle and side initiation, although middle initiation provides coarser average fragmentation than side initiation.

Figure 4 presents the maximum distance of fly rock. Locating primer at ten meters from the bench floor provides shorter distances of fly rock (about $70 \mathrm{~m}$ ) than the distance of fly rock when locating the primer at five meters from the bench floor $(80-90 \mathrm{~m})$. The nearest building to the quarry face is at a distance of about $500 \mathrm{~m}$. Hence, maximum distance of fly rock of 70-90 m has no potential of damage to buildings. However, excavators, loaders, drilling machines and other equipment have to be evacuated from the face to a safe distance and/or safe place. Difference in fly rock distance due to point of initiation is not significant.

Figures 5 and 6 illustrate the average height of muck pile. From Figure 5, the lower bench results in higher muck piles (up to $23 \mathrm{~m}$ ) than the height of muck piles from the upper bench (up to $14 \mathrm{~m}$ ). That is because the height of the lower bench (about $50 \mathrm{~m}$ ) is greater than the height of the upper bench (about $30 \mathrm{~m}$ ). In case of middle initiation, the height of muck pile is lower than the height of muck pile in case of side initiation. Effect of primer location is not that clear for middle initiation. However, for the upper bench, increasing the primer distance from the bottom lowers the height of muck pile in case of side initiation. Figure 6 shows that the height of muck pile as a percentage of bench height is higher for the upper bench (smaller bench height) than the percentage of the lower bench (greater bench height). In addition, primer located at $5 \mathrm{~m}$ from the bench floor provides acceptable percentage of muck pile height.

Maximum peak particle velocity (PPV) at definite distance from shot point is presented in Figure 7. In general, PPV is higher in case of side initiation than PPV in case of middle initiation. Looking for the effect of primer location in case of middle initiation, zero distance from the bench floor provides the lowest PPV. However, in case of side initiation, primer Location at $5 \mathrm{~m}$ from bench floor produces the lowest PPV. Measured PPV magnitudes are safe (much less than $5 \mathrm{~mm} / \mathrm{sec}$ ). Although these 


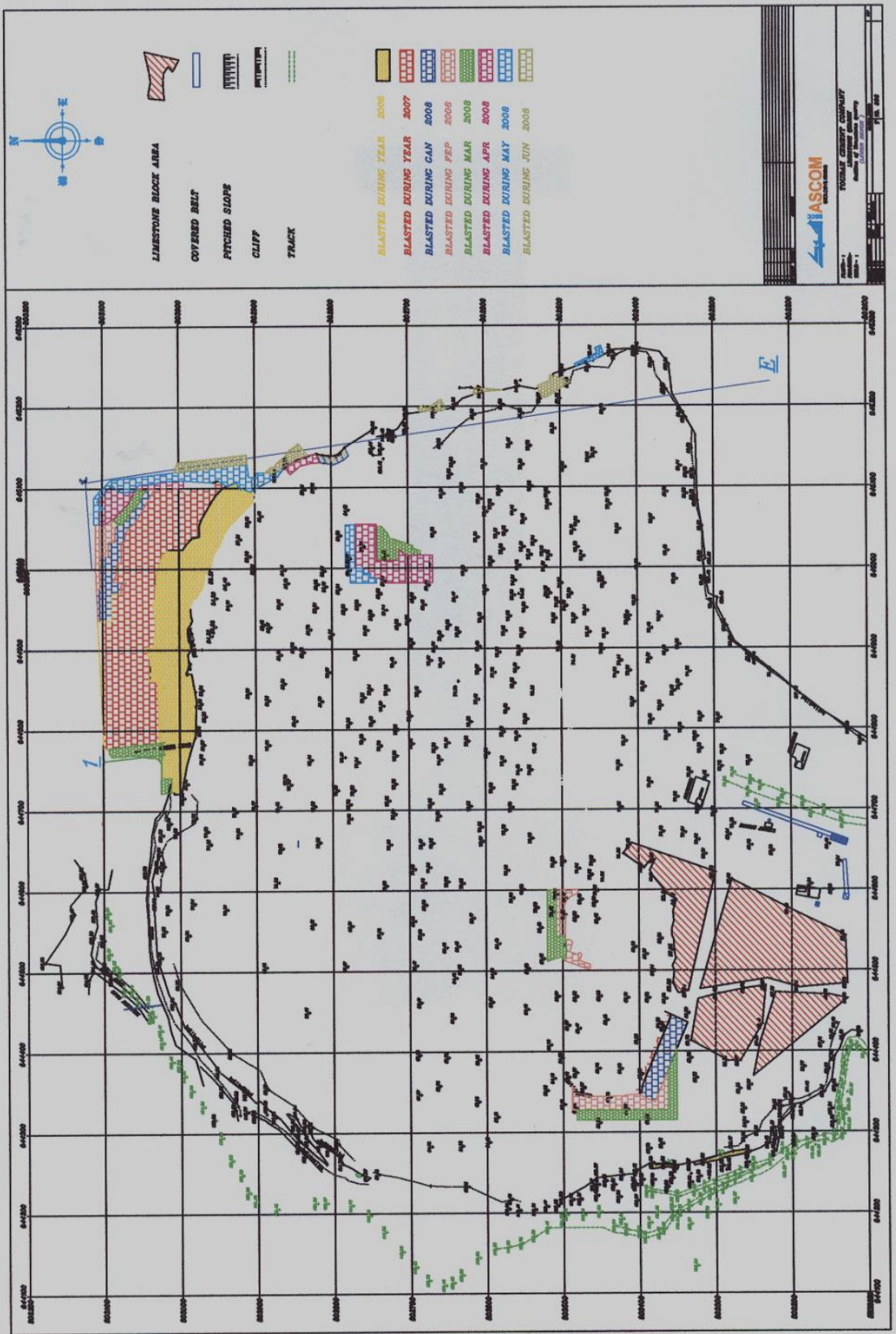

Figure 1: Topographic map for Tourah Quarry (After Khaled, M., Abdel Rahman, K., and Bagy, E. $)^{[13]}$. 
Table 1: Summary of average magnitudes of results.

\begin{tabular}{|c|c|c|c|c|c|c|c|}
\hline \multirow{3}{*}{ ـ } & \multirow{3}{*}{$\begin{array}{l}\text { Blasting } \\
\text { Output }\end{array}$} & \multicolumn{3}{|c|}{ Lower Bench } & \multicolumn{3}{|c|}{ Upper Bench } \\
\hline & & \multicolumn{3}{|c|}{$\begin{array}{l}\text { Primer Location From } \\
\text { Bench Floor, m }\end{array}$} & \multicolumn{3}{|c|}{$\begin{array}{l}\text { Primer Location from Bench } \\
\text { Floor, } \mathbf{m}\end{array}$} \\
\hline & & $0, \mathrm{~m}$ & $5, \mathrm{~m}$ & $10, \mathrm{~m}$ & $0, \mathrm{~m}$ & $5, \mathrm{~m}$ & $10, \mathrm{~m}$ \\
\hline \multirow{4}{*}{ 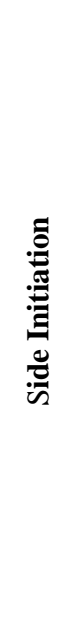 } & 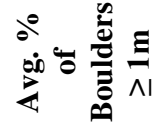 & 1.67 & 1.25 & 2.0 & 0.89 & 0.50 & 0.75 \\
\hline & 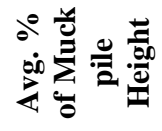 & 0.37 & 0.33 & 0.40 & 0.45 & 0.37 & 0.40 \\
\hline & 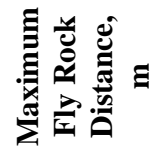 & 70 & 90 & 70 & 80 & 70 & 70 \\
\hline & 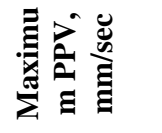 & 0.88 & 0.73 & 0.62 & 0.80 & 0.66 & 0.82 \\
\hline \multirow{4}{*}{ 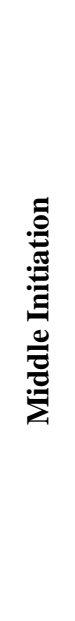 } & 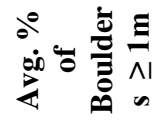 & 1.75 & 1.50 & 2.25 & 1.00 & 1.00 & 1.50 \\
\hline & 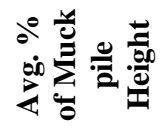 & 0.35 & 0.37 & 0.36 & 0.48 & 0.44 & 0.37 \\
\hline & 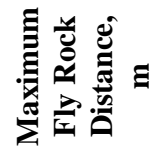 & 80 & 80 & 70 & 70 & 70 & 70 \\
\hline & 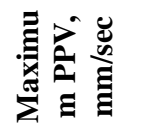 & 0.53 & 0.76 & 0.73 & 0.41 & 0.40 & 0.52 \\
\hline
\end{tabular}




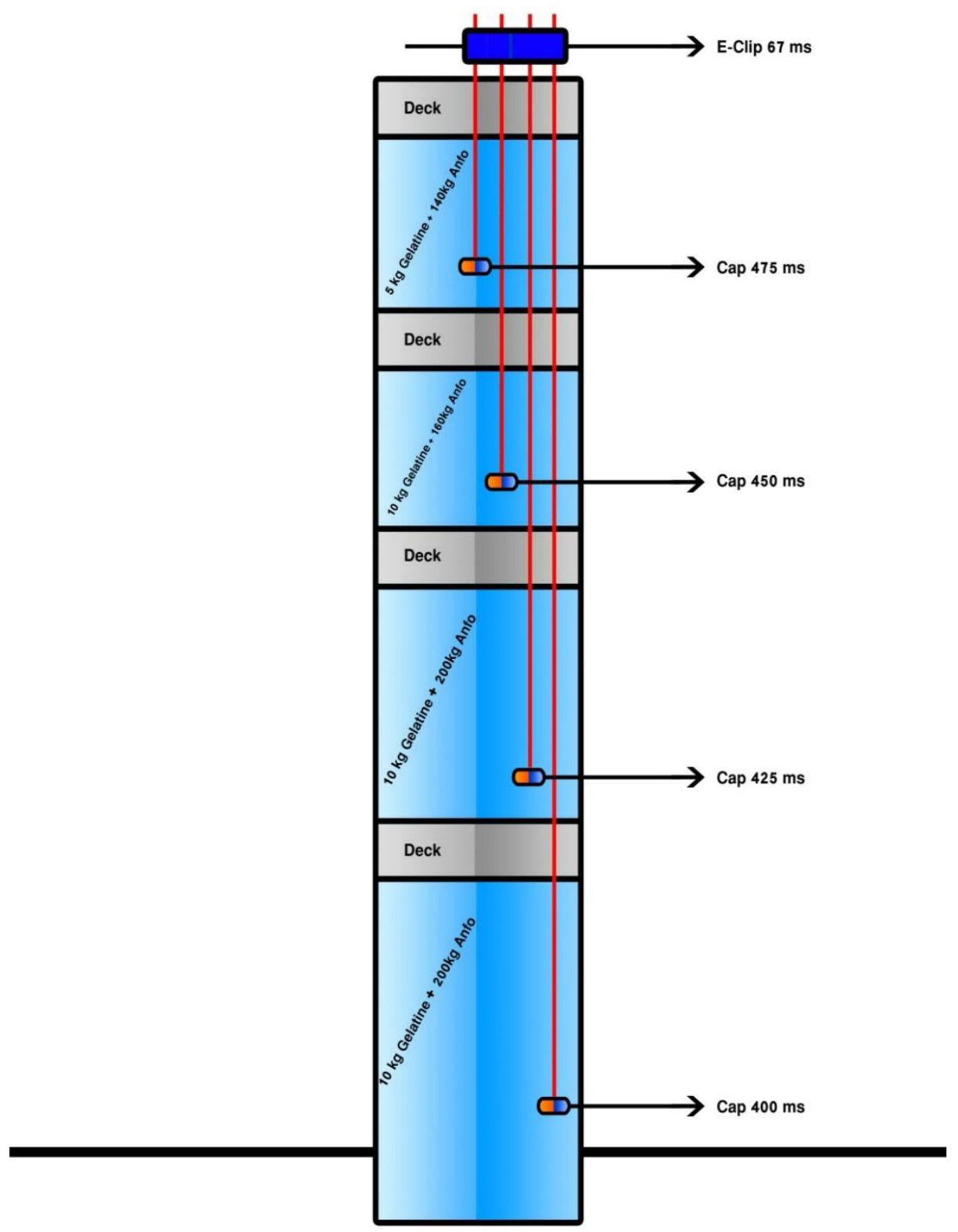

Hole Charging

Figure 2: An example of deck charging of the blast holes at the lower bench 


\section{Side Initiation}

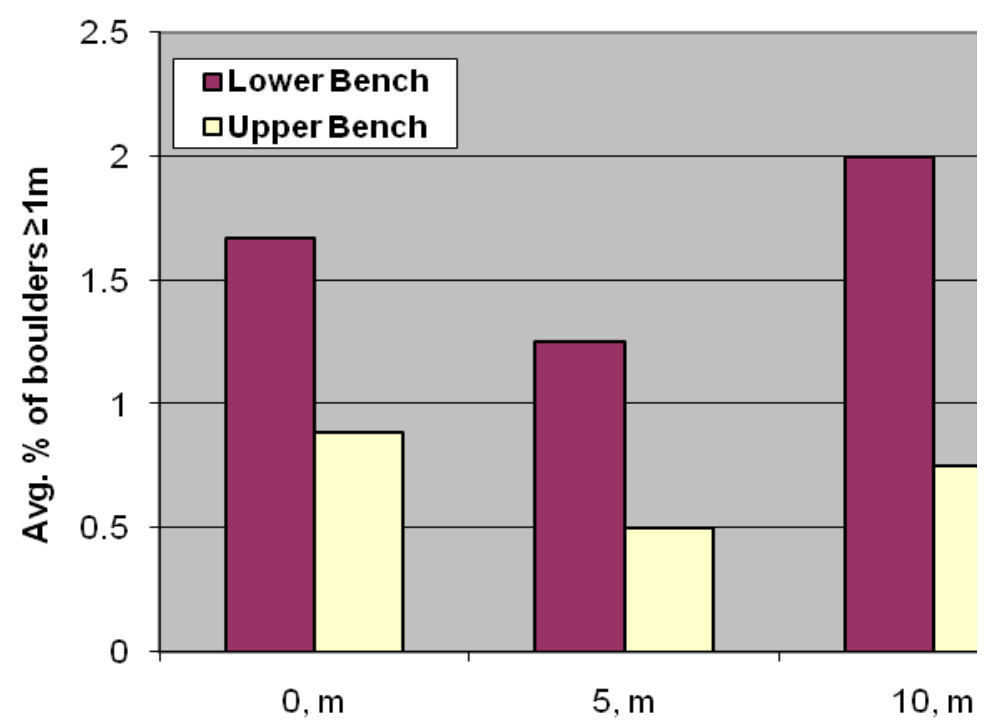

Primer location from bench floor, $m$

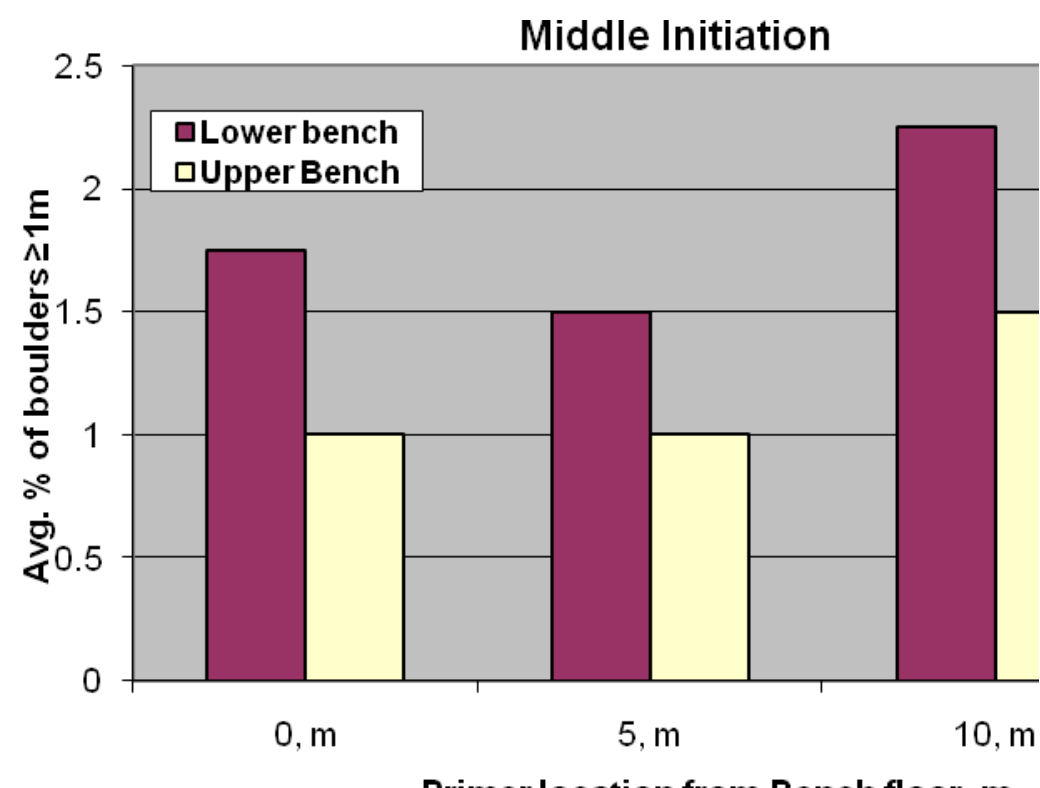

Primer location from Bench floor, $m$

Figure 3: Effect of primer location and point of initiation on percentage of oversize boulders. 

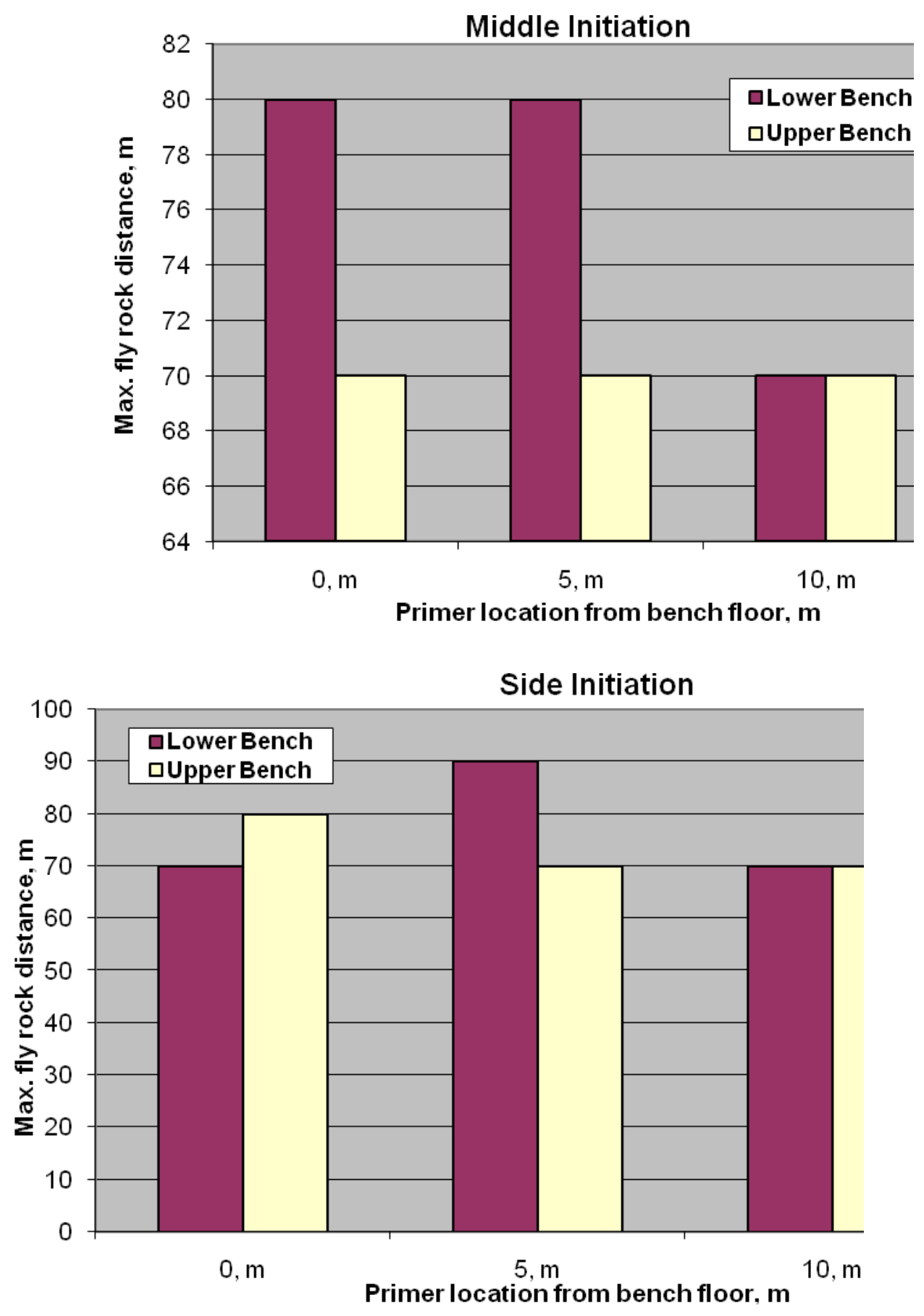

Figure 4: Effect of initiation point and primer location on maximum distance of fly rock. 


\section{Middle Initiation}
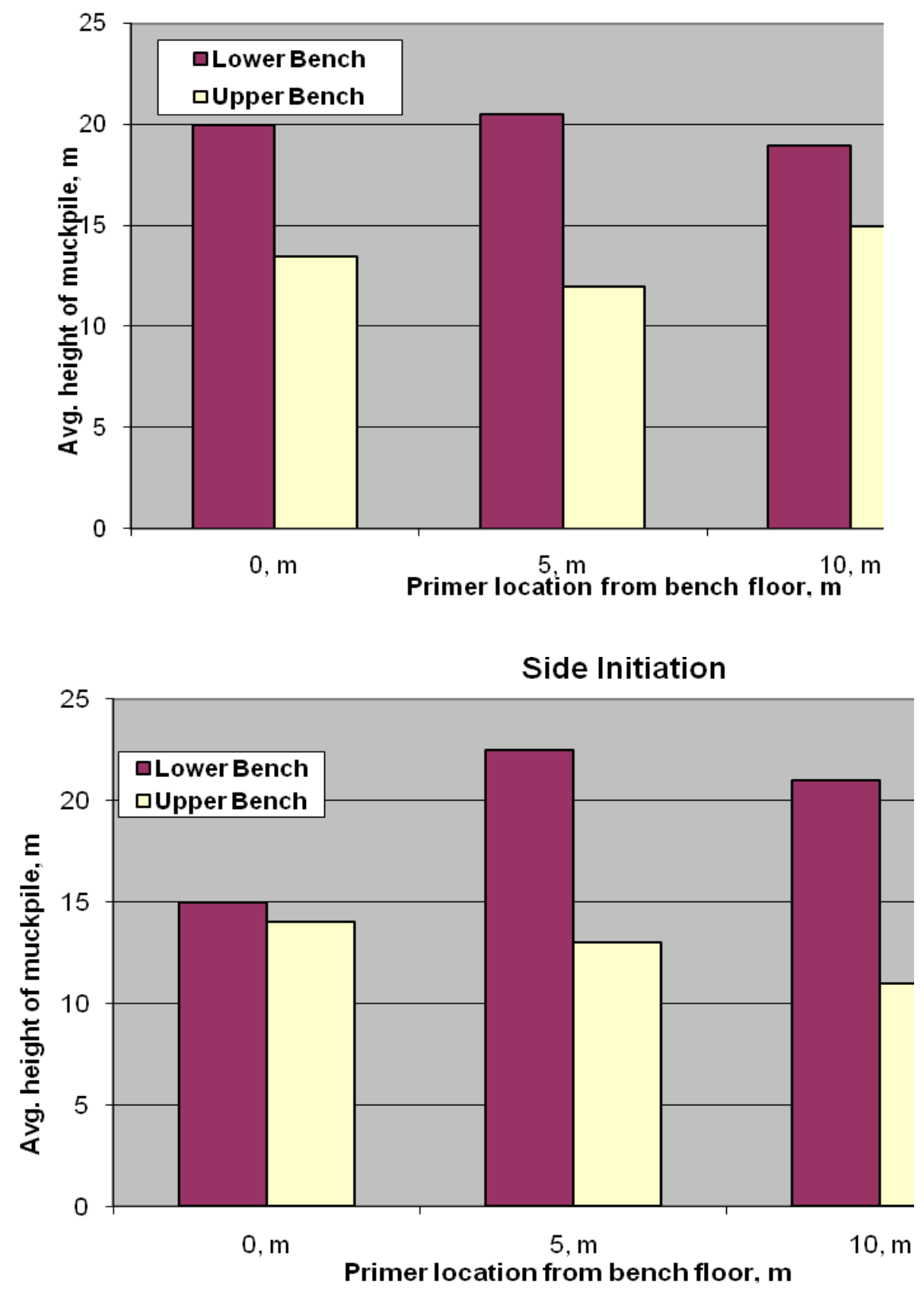

Figure 5: Effect of initiation point and primer location on average height of muck pile. 


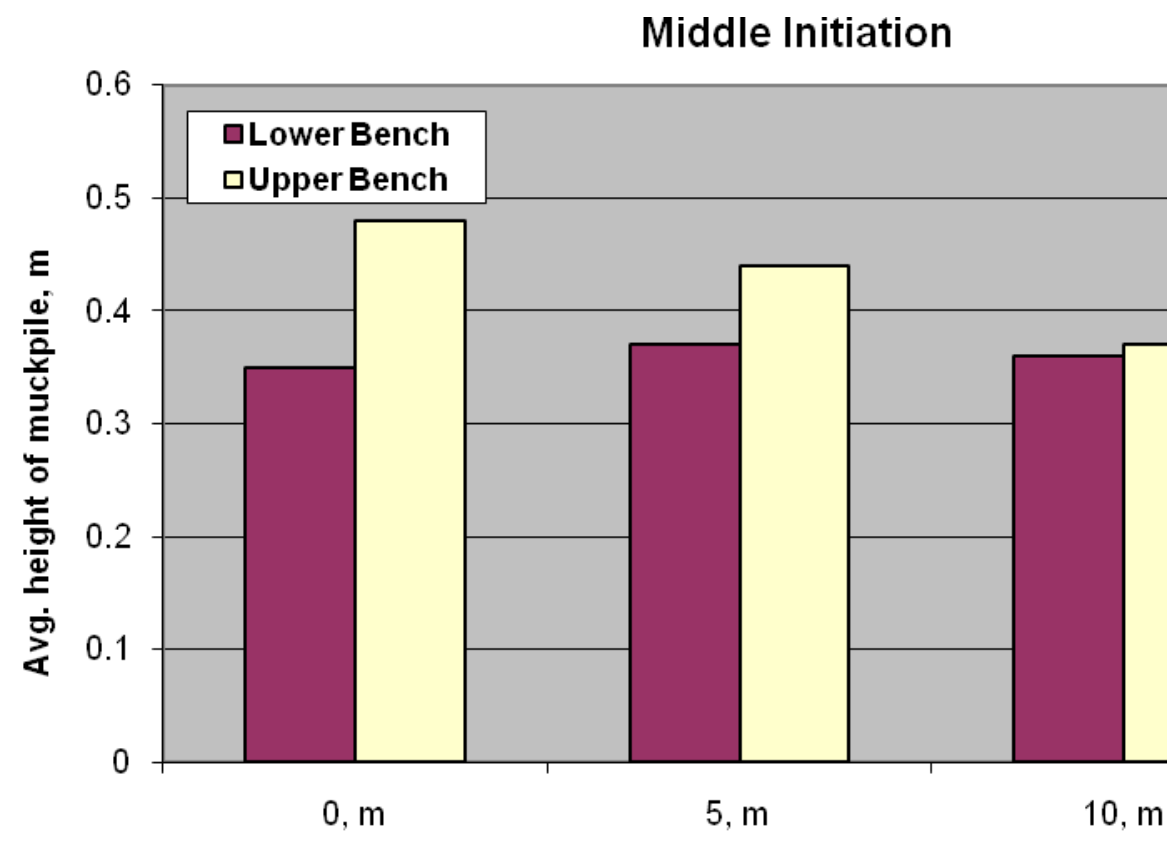

Primer location from bench floor, $m$

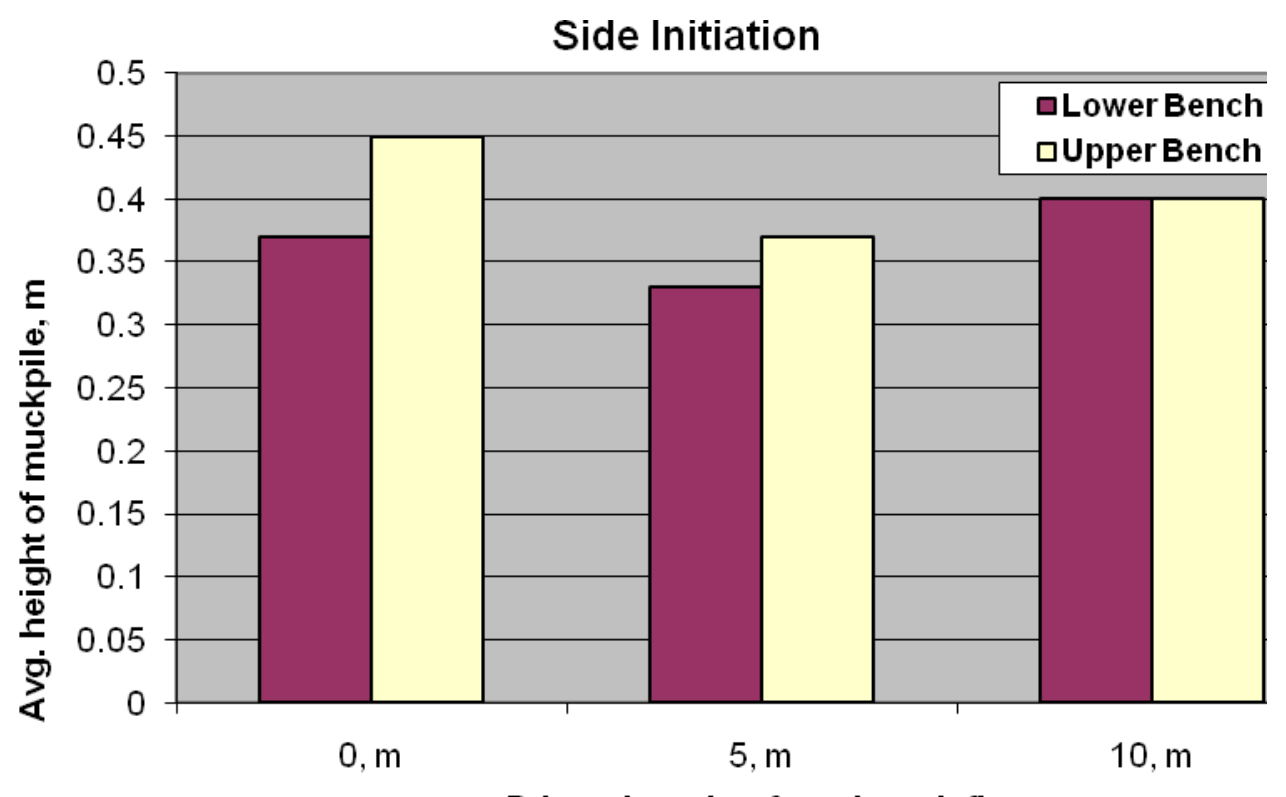

Figure 6: Effect of initiation point and primer location on relative height of muck pile. 


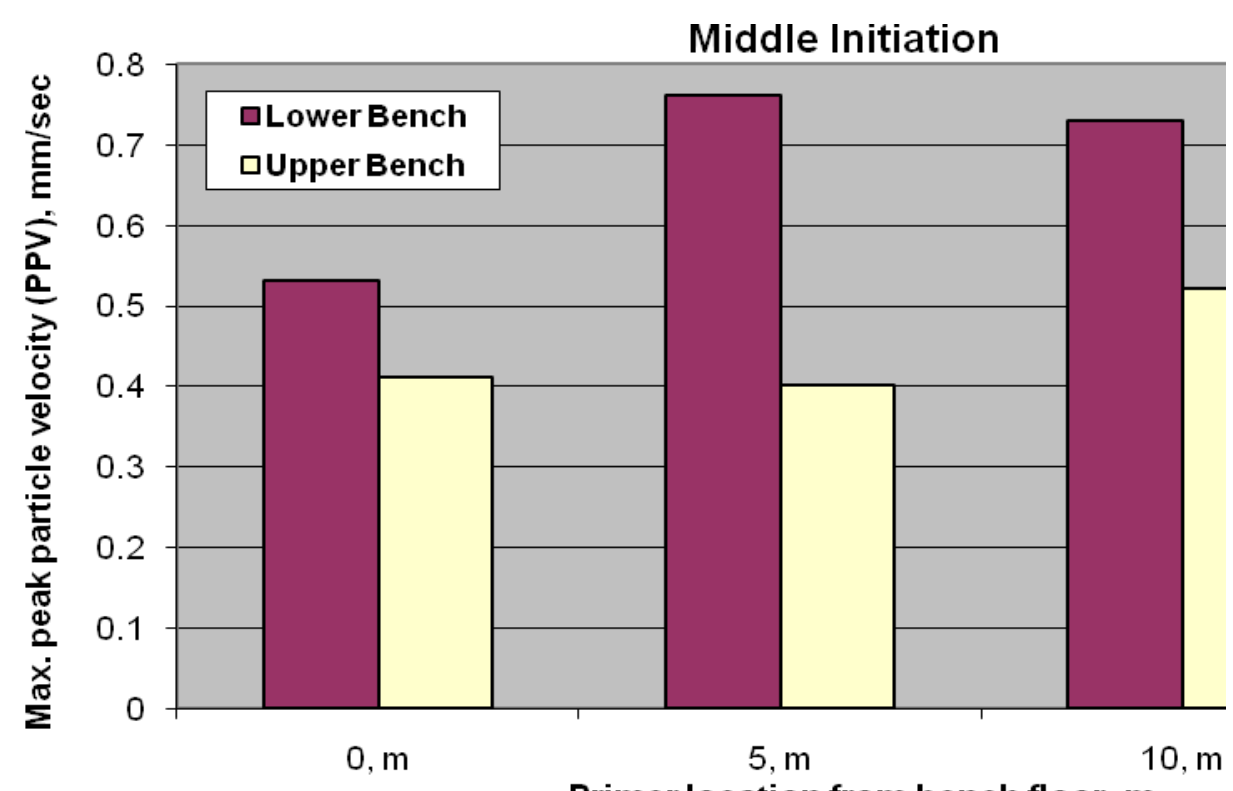

Primer location from bench floor, $m$

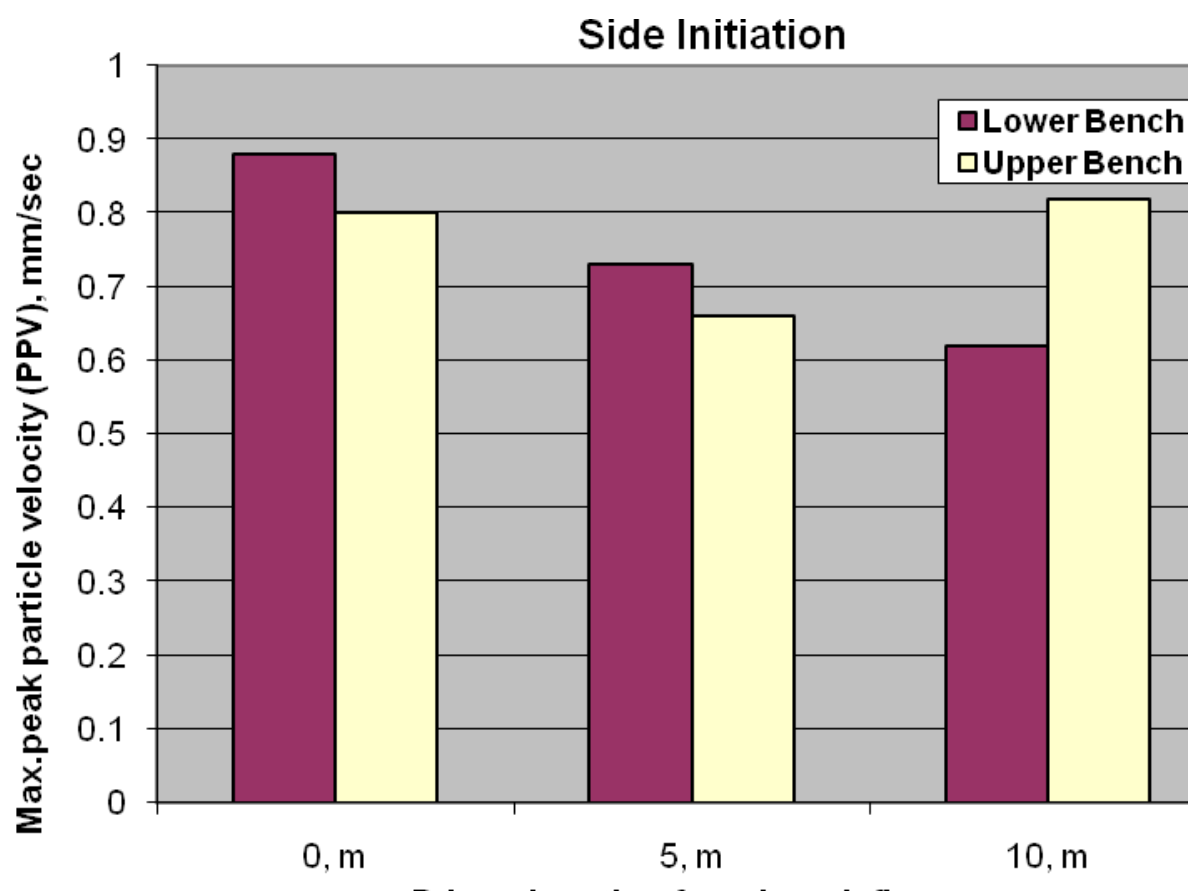

Primer location from bench floor, $m$

Figure 7: Effect of initiation point and primer location on peak particle velocity (PPV).

measurements are carried out at the historical caves (at a distance 1220-1300 m) from the face, quarry operators stated that they face no complaints at structures close to the 
face (at a distance of $500 \mathrm{~m}$ from the face). Hence, primer distance of $5 \mathrm{~m}$ above bench floor is acceptable.

From the previous analysis of data presented in Table1 and bar graphs, we can draw some conclusions. First, primer location at $5 \mathrm{~m}$ above bench floor is the optimum selection for the quarry. This location provides the least percentage of oversize for the two benches and the least PPV of ground vibrations for the upper bench. In addition, it provides acceptable distance of fly rock and relative height of muck pile. Second conclusion is about point of initiation. Side initiation results in lower percentage of oversize boulders and lower level of PPV of ground vibrations. In addition, side initiation provides acceptable distance of fly rock and muck pile height.

Those of us engaged in rock blasting realize the great number of bench blast parameters. Difficulty in selecting optimum magnitudes for these parameters is increased by the interrelations between them. We have different magnitudes for bench parameters during the study for example: height of bench, burden, stemming height...etc. This makes comparisons between results of different blasts inaccurate. To overcome this problem, we have made ratios between these parameters such as stemming $(\mathrm{T}) /$ burden $(\mathrm{B})$, total charge $\left(\mathrm{Q}_{\mathrm{T}}\right) /$ total height of bench $\left(\mathrm{H}_{\mathrm{T}}\right)$. In addition, these ratios provide a useful tool under the constraint of limited data points not enough for statistical analyses.

Figure 8 presents the dependency of percentage of oversize boulders on loading density and the volume of uncharged block $(\mathrm{B} * \mathrm{~S} * \mathrm{~T})$. Increase of the volume of the uncharged block leads to increase in the percentage of oversize boulders. That is because of the in-homogeneity of explosive energy distribution i.e. lack of explosive energy in the top portion of the bench. On the other hand, increasing the loading density decreases the percentage of the oversize boulders. That is because of the increase of explosive energy with increasing loading density.

Figure 9 illustrates the dependency of the percentage of oversize boulders on the spacing/burden and stemming/burden ratios. The figure shows that increasing S/B ratio than 1.45 would increase the percentage of oversize, this is according to the burdens at the site. In addition, increasing T/B ratio than 0.55 would increase the percentage of oversize due to lack of explosive energy close to the top of the bench.

Figure 10 shows the dependency of the ratio of the muck pile height to bench height on the loading density and burden/bench height ratio. Increasing loading density decreases muck pile height because it provides more explosive energy for displacement of fragmented rock. On the other hand, increasing $\mathrm{B} / \mathrm{H}$ ratio increases the muck pile height because the stiffness of the burden rock is increased. Increasing stiffness increases rock resistance to breakage. In addition, side initiation is known to provide more freedom for rocks to be displaced than middle initiation. Blasted rocks move in opposite directions in middle blasting whereas in side initiation there is one direction of movement. 

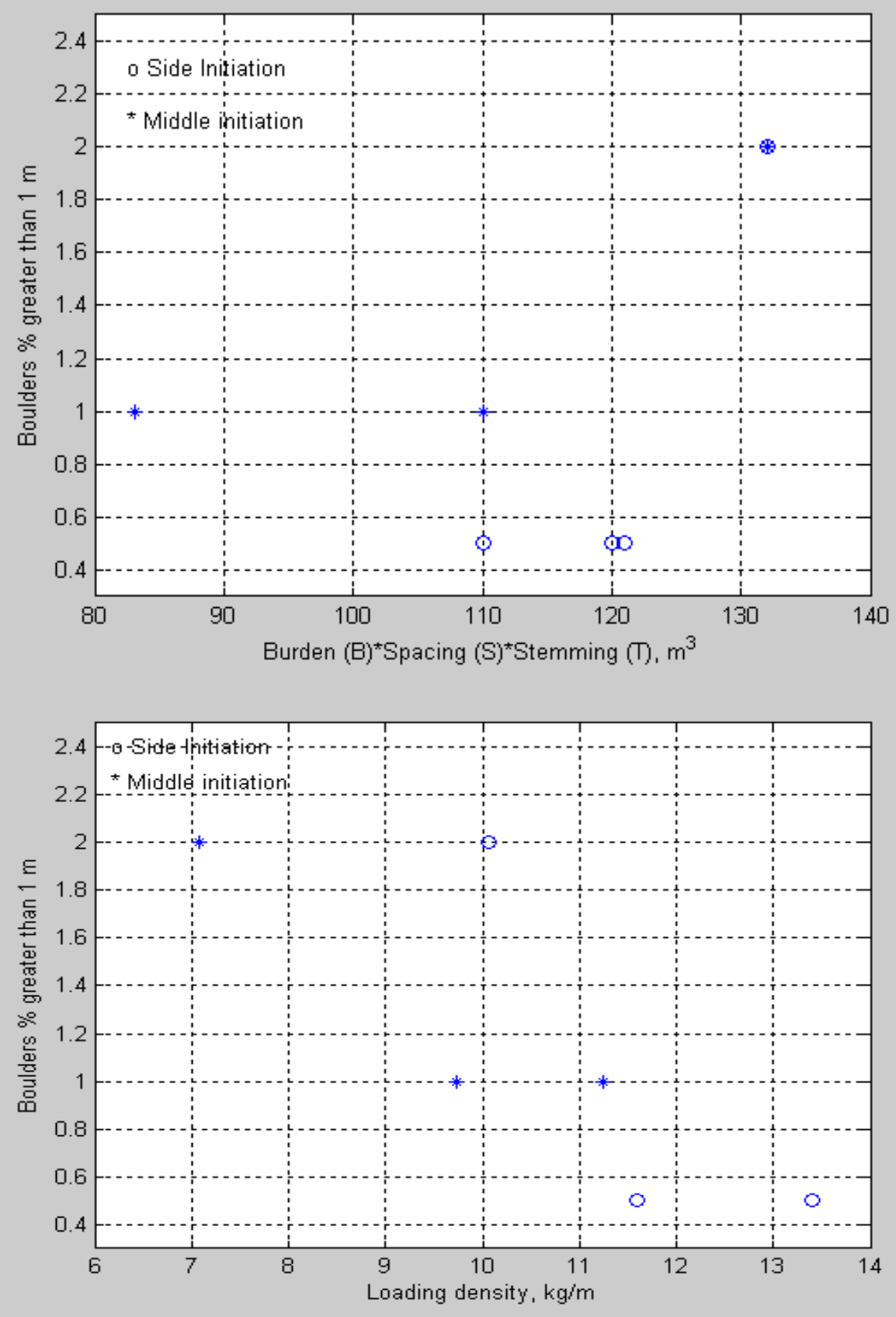

Figure 8: Dependency of percentage of oversize boulders on the uncharged block and loading density. 

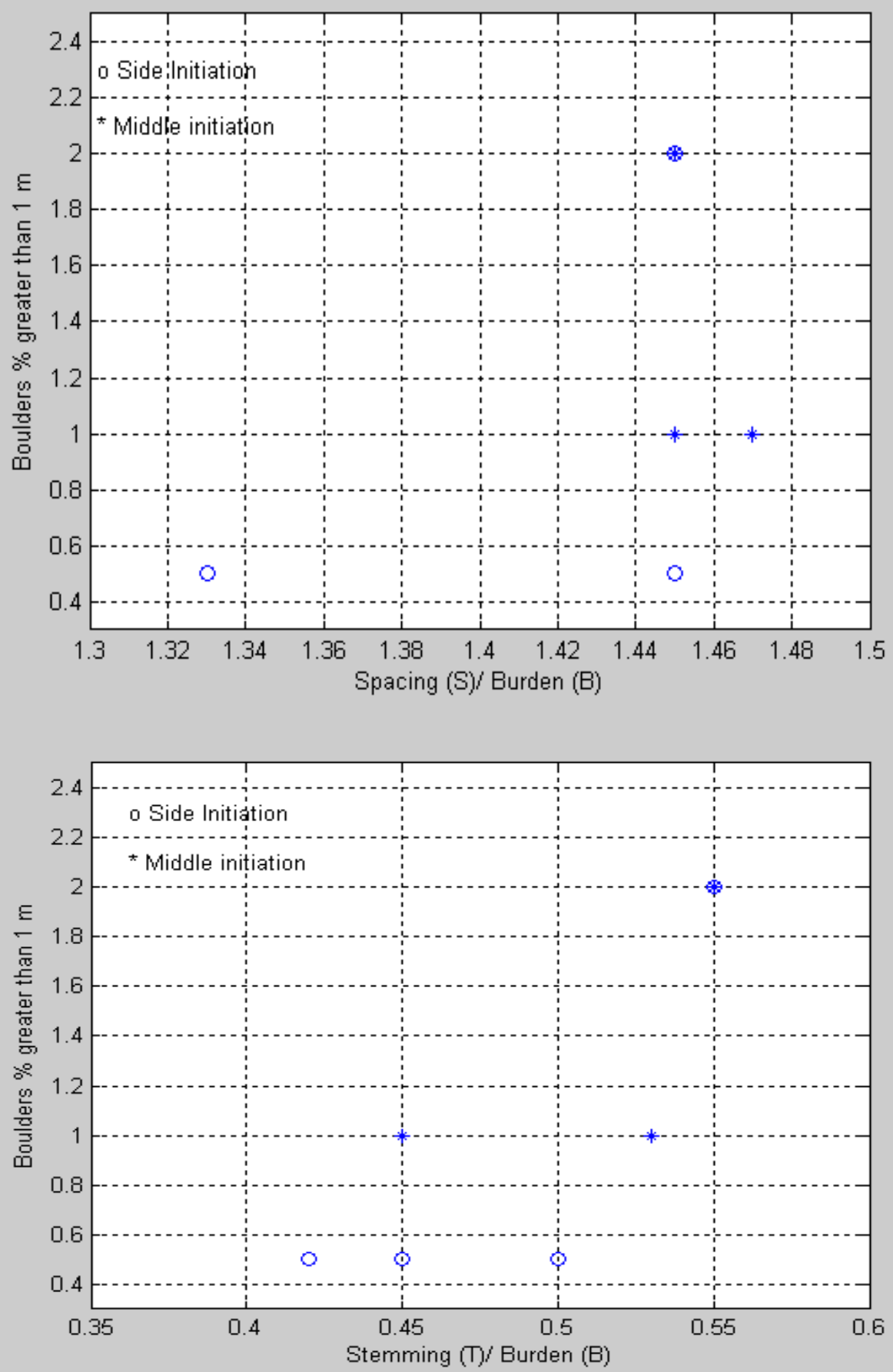

Figure 9: Dependency of percentage of oversize boulders on the spacing ratio and stemming ratio. 

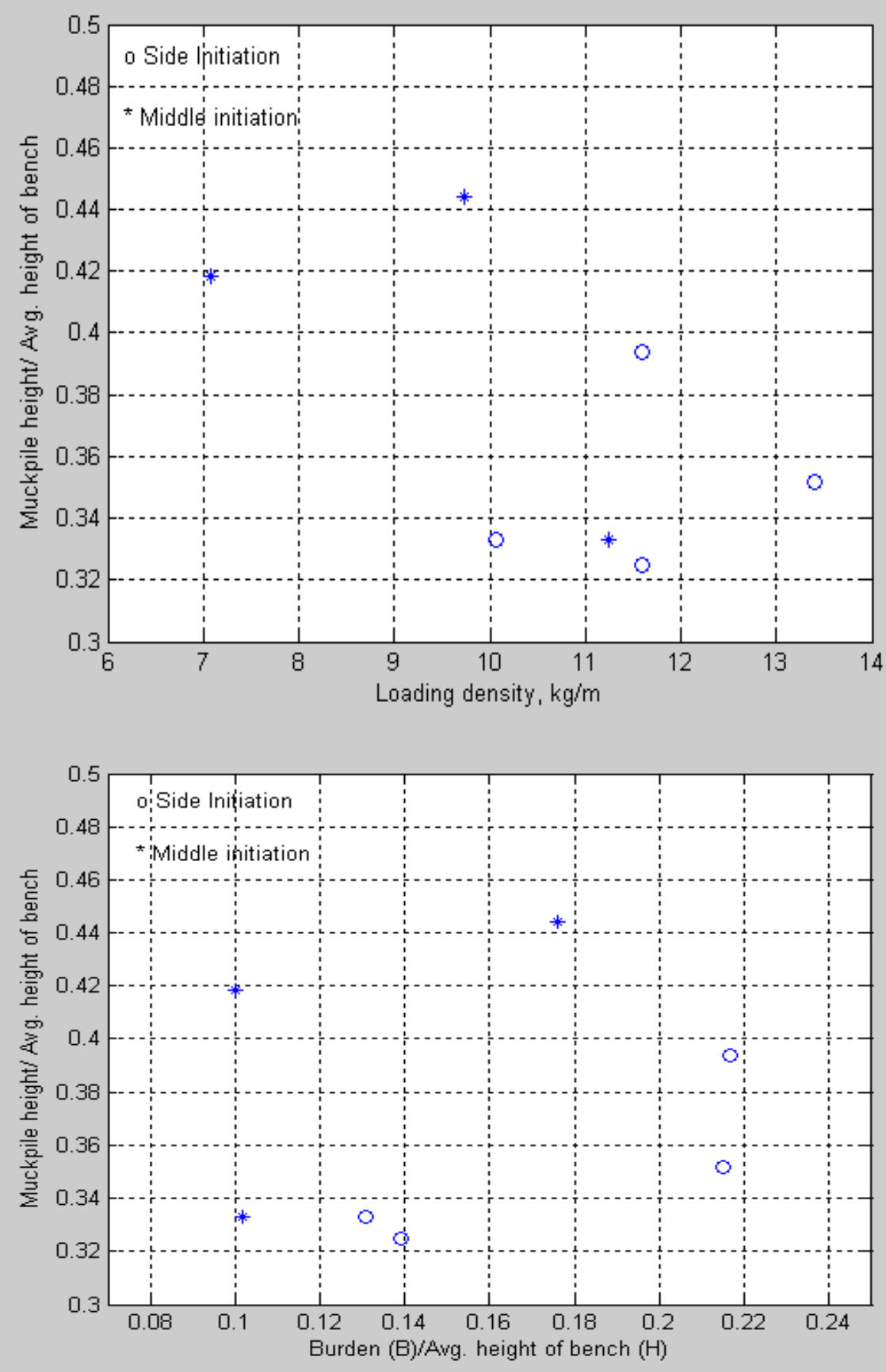

Figure 10: Dependency of the relative muck pile height on the burden/bench height- ratio and loading density.

Figure 11 presents the dependency of the maximum distance of fly rock on loading density and on T/B ratio. Increasing loading density increases the maximum 
distance of fly rock because it provides more explosive energy for throwing rock fragments. On the other hand, increasing T/B ratio decreases the maximum distance of fly rock because the explosive energy is confined for a longer time and chances of energy expenditure in rock fragmentation is more than energy expenditure in throwing rock fragments.

Figure 12 presents the dependency of PPV of ground vibrations on maximum explosive charge per delay. Increase of explosive charge per delay increases the explosive energy lost in ground vibrations.

\section{COCLUSIONS AND RECOMMENDATIONS}

Thirty full scale production blasts have carried out at Tourah-quarry, Helwan, Egypt. The results of the blasts have recorded and analyzed. From the analysis of the results, we can draw some conclusions and recommendations.

1- Primer location at $5 \mathrm{~m}$ above bench floor is the optimum selection for the quarry.

2- Side initiation of the blasts provides better results than middle initiation. The selection of these blast parameters results in lower percentage of oversize boulders and lower level of PPV of ground vibrations. In addition, it provides acceptable distance of fly rock and relative height of muck pile.

3- It is recommended to divide the lower bench into two benches. This division will provide lower muck pile heights and PPV. In addition, it will provide safer and more efficient work place.

4- In the quarry conditions, increasing burden-spacing ratio than 1.45 and increasing stemming-burden ratio than 0.55 leads to increase oversize boulders in the blast results.

5- Increasing loading density increases maximum distance of fly rock, improves fragmentation, decreases muck pile height and increases ground vibrations. 

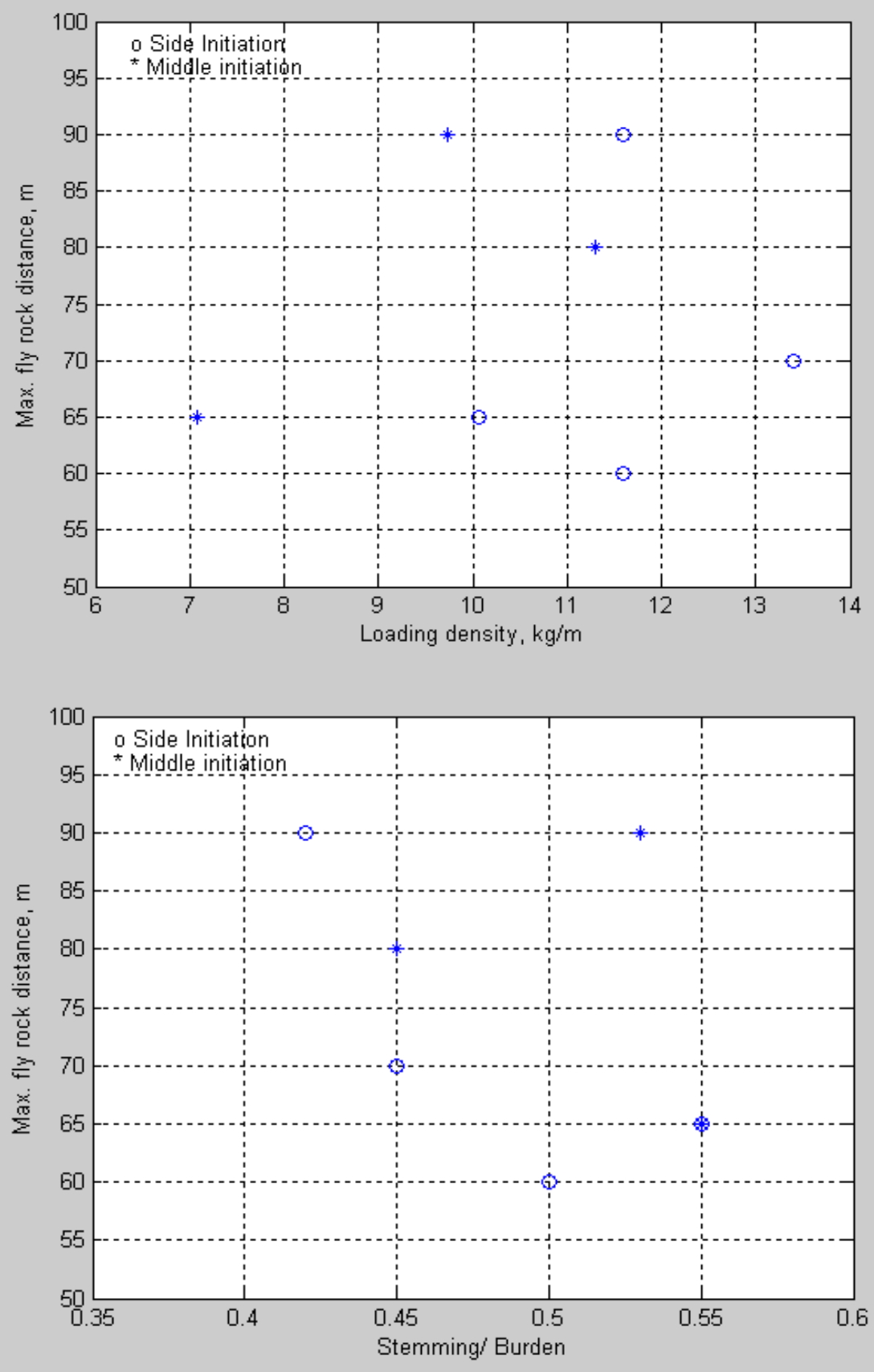

Figure 11: Dependency of the maximum distance of fly rock on the loading density and Stemming/ burden-ratio. 


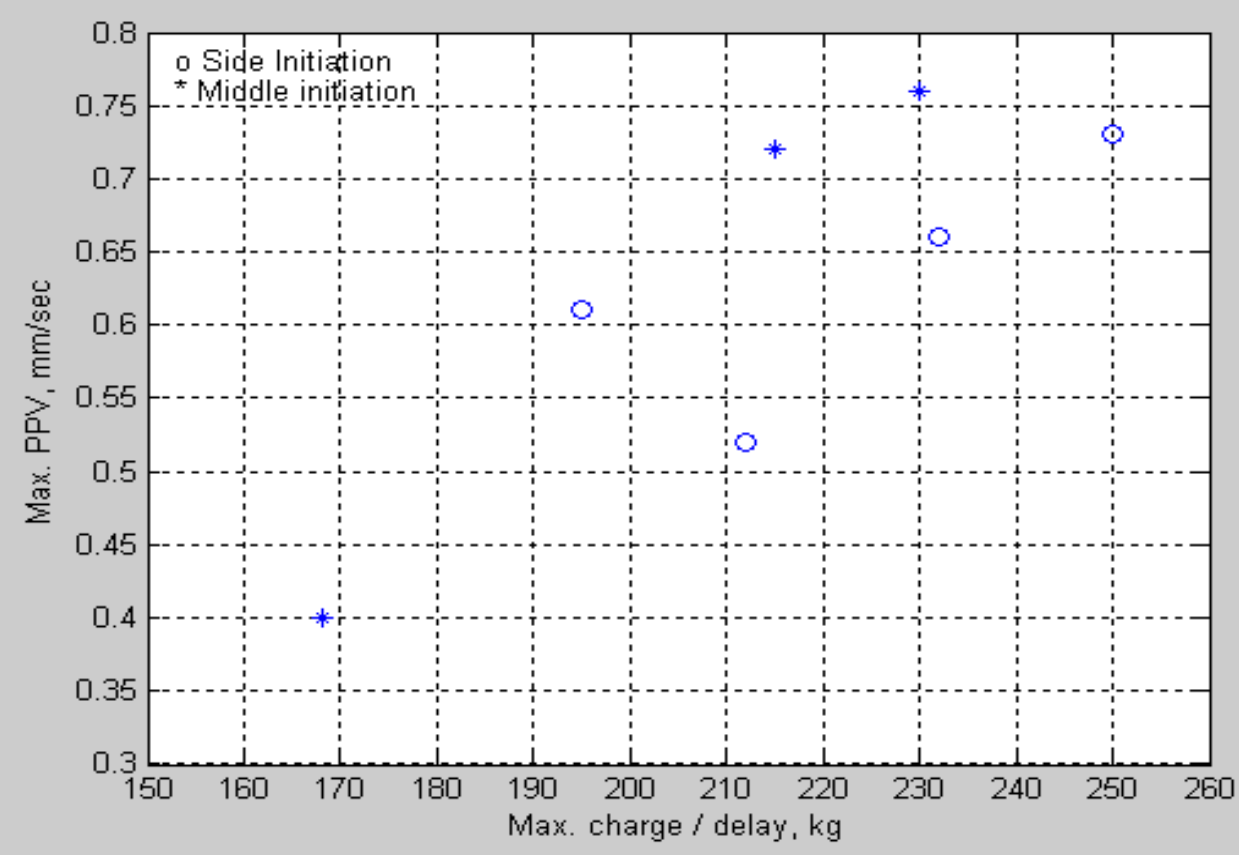

Figure 12: Dependency of the peak particle velocity on the maximum charge per delay.

\section{ACKNOWLEDGEMENTS}

The authors express their gratitude to Emad Bagy of ASCOM Egypt who provided excellent cooperation during measurements and recording of results.

\section{REFERENCES}

1. L. Gertsch and J. Baird, "A Phased Array Approach to Rock Blasting", Final Technical Report, University of Missouri-Rolla Rock Mechanics \& Explosives Research Center Rolla, August 2006.

2. A. Kahriman, G.Tuncer \& A. Karadogan, "A Practical Approach For Blasters to Determine The Optimal Bench Blasting Conditions", International Society of Explosives Engineers, Volume 1, 2004G.

3. Atlas of Powder Company, "Explosives and rock blasting", Field Tech. Operations", Atlas Powder Co., Dallas, Texas USA, (1987).

4. Konya, C. J. and E. J. Walter, "Rock blasting", U. S. Dept of Transportation, Federal High Way Administration, Virginia, (1985).

5. Olofsson S. O., "Applied Explosives Technology for Construction and Mining", Nitro Nobel Hand Book, Arla, Sweden, (1990).

6. Tamrock, "Surface Drilling and Blasting", Tamrock Hand Book, Tamrock Publisher, Finland, (1984). 
7. Singh B., and Pal Roy P. ,"Blasting in Ground Excavation and Mines", Hand Book, Dhanbad, India, (1993).

8. Langefors, U. and Kihlstrom, B., "The Modern Technique of Rock

9. Blasting”, John Wiley \& Sons, Inc., Sweden, (1967).

10. Hatem Adly Sultan, Elseman I. Abdel Rasoul, Moamed Abuel Kassem, Mostafa M. Elbeblawi, Mamdouh Yousef Hussien, "Suitable stemming type and length improves safety and efficiency of bench blasts", J. of Eng. Sciences, Assiut University, Vol. 33,No. 3, pp. 955 - 971, May 2005.

11. Hatem Adly Sultan, Elseman I. Abdel Rasoul, Moamed Abuel Kassem, Mostafa M. Elbeblawi, Mamdouh Yousef Hussien, "Optimization of blasthole burden, spacing, inclination, and delay time for the limestone quarries of Assiut Cement Company", The $9^{\text {th }}$ Int. Mining, Petroleum, and Metallurgical Eng., Cairo university, Cairo, February 21-24, 2005.

12. Mostafa F. Rashad, "Geological and Geotechnical Characteristics of some Limestone Deposits used in Cement Industry - South Wadi Garawi, East of Helwan" M. Sc thesis, Faculty of Science, Cairo University, 1993.

13. Khaled, M., Abdel Rahman, K., and Bagy, E.," Topographic map for Tourah Quarry", Personal Communications, 2009.

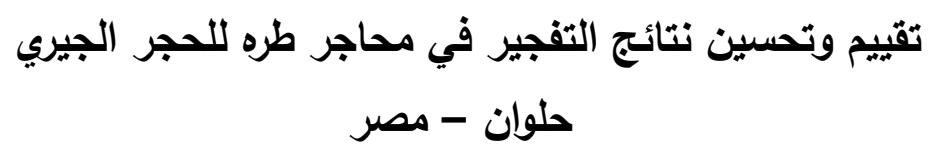

تقييم أداء التفجيرات يعتبر ذو قيمة عالية لمشغلي المحاجر لتحسين نتائج عمليات التفجير ـ الهدف من

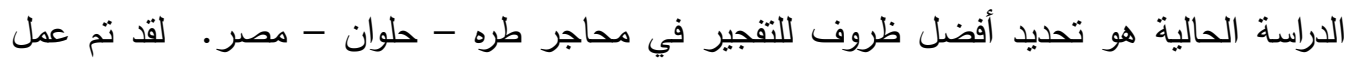
توجيهات خطوة- خطوة لتنفيذ تفجيرات تجريبية لنقيبم نتائج التفجير في المحجر ـ ـ لقد نم إجراء 30 ضربية إنتاج كاملة في المحجر وتم تسجيل النتائج. حيث تم دراسة متغيرين من متغيرات التصميم وهما نقطة البدء وموقع البادئ داخل ثقب التفجير • وكان الهدف هو الحصول على أفضل أفضل نتائج تفجير : درجة إزاحة وانتفاش مناسبين للحجر المفجر - أفضل درجة من التكسير والتحبب - أقل درجة من عدم استواء

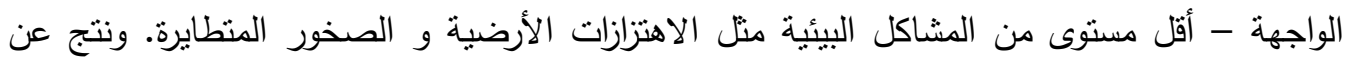

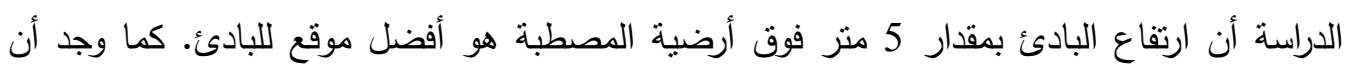

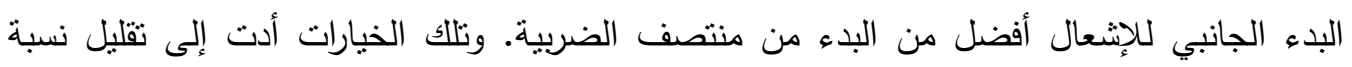
الأحجام الكبيرة من الصخور وتقليل الاهتزازات الأرضية مع المحافظة على مسافة مقبولة للصخور المنطايرة وارتفاع مقبول للصخور المتكسرة. 